\title{
Honor-Based Violence in Sweden - Norms of Honor and Chastity
}

\author{
Siv-Britt Björktomta ${ }^{1}$ (D
}

Published online: 21 February 2019

(C) The Author(s) 2019

\begin{abstract}
This article investigates the nature of honor-related domestic violence as experienced by 11 young female victims (aged 16-20) with non-Swedish-born parents. It examines what forms of violence are involved and how they are related to each other and looks at the differences and similarities to non-honor-related domestic violence. Qualitative, individual interviews were made with young women who, when in contact with counselors, mid-wives or social workers, said that they were living with restrictions over their social life and sexuality with some level of control imposed by another person. Accordingly, it is young women's subjective assessment of their experience which defined their inclusion in this study. The analysis has been a recursive process with a theory-oriented approach that uses Bourdieu's concept of symbolic violence as a theoretical lens. The participants belonged to patriarchal families in a particular cultural/religious community and lived under various types of coercive control. For the participants, the core concept of the family norms was twofold: honor and firm demands for chastity. There was a strong link between the restrictions they experienced and their vulnerability to various forms of violence, alongside accounts of strong emotional ties between father and daughter, in most cases. The participants' scope for action was affected irrespective of they were physically abused or not. The findings contribute to an initial understanding of how nonviolent controlling behaviors affect young women's scope for action and highlight daughters' vulnerable situation in a patriarchal family.
\end{abstract}

Keywords Honor-based violence · Symbolic violence · Coercive control · Young women · Patriarchal family · Chastity · Honor · Qualitative method

\section{Introduction}

\section{Domestic Violence: Honor-Based Violence}

Domestic violence, DV, is a global issue; it is gendered and has no class, ethnic, cultural, or religious boundaries (Nason-Clark 2004). It is a complex phenomenon taking various forms (Johnson 2006; Stark 2009). Johnson (2006) notes that the diverse types of violence have different underlying causes that develop in various ways and therefore have different consequences for the victims. The different types of violence require different forms of intervention and support.

In recent years, a particular form of violence, termed honorbased violence, HBV, has been on the agenda (Ertürk 2009; Gill 2014). This type of violence has been categorized as a

Siv-Britt Björktomta

siv-britt.bjorktomta@soc.uu.se

1 CESAR - Centre for Social Work, Uppsala University, Uppsala, Sweden specific form of gendered-based violence; however, there is no one accepted definition of the concept (Author 2007; Bates 2017). Despite the lack of a clear definition, there is a consensus about crimes of honor as a worldwide problem, with an estimated 5000 women and children murdered each year (UNFPA 2000).

The concept of honor is about morality and can be interpreted as a general phenomenon linked to a basic human need to be recognized by the social context. Thus, honor and norms of honor have different meanings in different societies and in different social and cultural contexts. Moreover, the concepts change over time (Ertürk 2009; Hayes et al. 2016). In societies with an honor-based value system, honor refers to "the regulation of women's sexuality and their conformity with social norms and traditions" (Gill 2014, p. 2). In these contexts, honor plays a key role in families' daily lives and encompasses not only the individual's own worth and self-esteem but also that of the whole family. To preserve its honor, the family, i.e., the father, is dependent on recognition from the social context (Bourdieu 1999; Gill 2014). A family's honor can also be sullied due to family members' actions, e.g., a daughter's immoral 
conduct. This may have severe consequences for the daughter: emotional, physical, and social (Author 2012; Gill 2014). Due to social and cultural variation in the interpretation of honor, honor crimes differ according to the societal context (Hayes et al. 2016).

Honor-based violence has usually been framed within the broader spectrum of Violence Against Women either as part of men's violence against women or as a specific form of violence linked to an honor culture (Carbin 2013; Ertürk 2009; Gill 2014) but more rarely as expressions of child abuse, child maltreatment, or parents' violence against children/young people, or brothers' violence against sisters. This article contributes to a growing knowledge on how nonviolent controlling behaviors affect children's, i.e., daughters', scope for action. It is also a contribution to a discussion of the differences and similarities between domestic and honor-based violence. The data consist of interviews with 11 young female victims (aged 16-20) with non-Swedish-born parents. The data collection was carried out as part of a major research project, and for the current analysis, the data has been reread and reanalyzed.

\section{Aim}

This article investigates the nature of honor-based domestic violence as experienced by young female victims. It does so by posing the following research questions:

- What types of violence are involved (social, psychological, physical)?

- How are the different types of violence linked?

- Does the context of honor and patriarchy contribute to the violence and, in that case, how?

- What are the differences and similarities to non-honorrelated domestic violence?

\section{Literature Review}

The following three sections presents literature about children's experiences of DV, about violence and gender, norms and religion and, finally, literature about young women and honor-based violence. The themes are chosen to underpin the theoretical framework.

\section{Children's Experiences of Domestic Violence}

Efforts to prevent DV, including child abuse, have been on the agenda for decades, but still remain a global public health problem. A broad overview of research on physical punishment of children indicates that corporal punishment, as an integral part of child rearing, has no lasting positive effect.
In addition, corporal punishment often tends to escalate into more severe forms of violence (Grogan-Kaylor et al. 2018). Childhood physical abuse entails a risk of serious injury and even death. Moreover, violence is a stress factor impacting the child and can lead to poorer school performance, mental illness, eating disorders, and deliberate self-harm (Jernbro and Janson 2017; Jernbro et al. 2010).

Nevertheless, it is not just the physical violence that affects children. In interviews with 15 mothers exposed to IPV and 15 children (10-14 years old) from 15 families, Katz (2015) shows the harmful impacts of living with what Stark (2009) termed coercive control. One example is how fathers succeed in maintaining their dominance in families by monopolizing mothers' time. In many cases, this means that children have less time with their mothers. In different ways, fathers' coercive control restricted children's scope for action as well as their freedom to say and do things. But their scope for action was also restricted by the children themselves as a way of avoiding abuse.

Being exposed - witnessing or being abused - to violence is a frightening experience. But in interviews with children living with their mothers in domestic violence shelters in Norway, Øverlien (2013) identifies a group of children (820 years old) who more than the other children expressed what was described as a more "all-embracing" violence. These children had lived in a special family situation with a male perpetrator using systematic violence. The children expressed their experiences in words but also in their body language and tone of voice, giving accounts of a strong sense of fear. They described an ever-present psychological violence with coercive control and different forms of threat. The threats were both verbal and nonverbal and involved promises of different forms of violence directed at their mothers or at the children themselves. For this group of children, the violence was "an integral part of their lives, it was as embodied" (Øverlien 2013, p. 284).

Parenthood makes it possible to exert control over the child in ways that one may not always be aware of. So the perpetrator being a father and an attachment person is a special consideration. From a child's perspective, Cater and Sjögren (2016) created a typology of 10 children's experiences of parents' IPV. The children were 8-12 years of age and living in women's shelters in Sweden. The first type was called Obedience-Demanding Violence, identified by four children, and described a pattern of violence employed in specific situations, e.g., when the father was drunk, the children had been disobedient, or there had been an accident. This violence was understandable and could be avoided by being obedient. The second type, Chronic and Mean Violence identified by three children, comprises violence and threats of violence from an evil father. To protect themselves from the violence, the children tried to avoid interacting with their fathers as much as possible. Finally, the third type, Parenthood-Embedded 
Violence identified by three children, was more closely interpreted as connected to the perpetrator's role as a father. However, the picture the children painted of their fathers was contradictory or ambivalent. On the one hand, the children said they longed for a close relationship with a loving and caring father, and, on the other hand, they described negative situations and violent acts that the father had committed.

In a five-year longitudinal study of young children's experiences of DV, 15 teenagers (aged 15 and 16) described their family situations in a similar way (Weinehall 1997/2005). There was no mealtime structure, bedtime structure, etc., and the father set the family rules, but they were unpredictable and difficult to obey, and the teenagers never knew when or why a violent situation might arise. Also, the violence was unpredictable, constant, and frightening and was mostly meted out by a drunken and pugnacious father or stepfather. It affected both the mothers and the teenagers in various ways. Moreover, it was the psychological violence the teenagers considered the worst of all.

Research points to the child's vulnerable position in the family (Øverlien 2013; Katz 2015), and the importance for children to experience and develop positive close, and longterm relationships with adults (Durrant and Ensom 2017). DV involving children not only encompasses physical violence; it also includes a wide range of controlling behaviors, psychological abuse, e.g., restrictions on the right to choose how to act, think, and feel (Katz 2015; Weinehall 1997/2005; Øverlien 2013). Taken together, DV involving children is about a permanent attitude held by the parents or guardians that destroys, or prevents, the child from developing a positive self-image. According to children, psychological violence and neglect are far worse than physical violence (Weinehall 1997/ 2005; Jernbro and Janson 2017).

\section{Violence and Gender: Norms and Religion}

Gender is an important aspect of DV, with the World Health Organization (2007) and academic research asserting that stereotyped gender norms are related to violence worldwide (Berkel et al. 2004; Smagur et al. 2017; Westenberg 2017). We know that girls and women report more child abuse than boys and men in home environments as well as exposure to several forms of violence (ONS 2018). Findings indicate that gender-typed gender roles could be a risk factor for behavior problems in IPV-exposed children, although the findings are mixed as to whether boys and girls are affected differently (Smagur et al. 2017). However, Smagur et al. (2017) point to gender norms as well as social expectations for boys and girls within both the family and the larger societal context as important elements for understanding the mixed findings.

Religious traditions have a specific function concerning family, gender, and sexuality norms (Nason-Clark 2004; Westenberg 2017). Historically, Islam, Judaism, and
Christianity have greatly influenced family values and sexuality. All three religions emphasize traditional family values and complementary gender roles, often combined with a negative attitude toward divorce. These religious discourses can have a supporting role for the family and the individual. On the other hand, in cases of domestic violence, a strong discourse on male authority, the sacred nature of marriage, and the woman's role as a wife and mother can also prevent female victims from seeking help and leaving an abusive relationship (Nason-Clark et al. 2017). A study of Christian families indicate that the language of forgiveness can support an idea at the same time as perpetuating and tolerating power and abuse (Westenberg 2017).

The increasing interest in exploring different aspects of children's experiences of violence has revealed how important it is to observe the complexity of DV and that analyses of the whole context, not just the acts of violence, are needed. In the most recent Swedish national survey of upper secondary school students' experiences of violence (4700 students aged between 15 and 17), questions about the perceived freedom to make one's own decisions were added for the first time (Jernbro and Janson 2017). The survey contained questions about appearance, clothes, friends, leisure time, education, religion, political/ideological views, and choice of marital partner. The findings showed that a group of students, mostly with non-Nordic-born parents, reported experiencing control and restriction in their daily lives. The survey also highlighted a strong link between the restrictions experienced and vulnerability to various forms of DV. Altogether, this spotlights the role of discourses, religions, norms, and our expectations about gender and gender roles and their impact on domestic violence.

\section{Young Women and Honor-Based Violence}

This last section looks at research on girls and women in Western countries who are from ethnic minority families and have to live their lives in accordance with an honor code.

Despite the discussion about how to define HBV, there is a growing body of research on this type of violence, the most common being surveys or legal documents studies (Bates 2017; Hayes et al. 2016; Schlytter and Linell 2010), but there are also some small qualitative interview studies with female victims (Blum et al. 2016; Author 2012). The most common and significant aspect of this body of research is the victims' extraordinarily vulnerable situation. Furthermore, women and girls exposed to HBV are described as being in an overall complex situation with several parallel and extremely difficult problems (Blum et al. 2016; Schlytter and Linell 2010). The majority of this cohort have experienced migration, either firsthand or through their families' experiences. Research indicates that due to these experiences, this group has both a greater and more prolonged need for support, both with 
practical matters and with building new social networks that can replace the loss of the family (Danneskiold-Samsøe et al. 2011). Furthermore, girls and women in domestic violence shelters show more disturbed night's sleep, i.e., nightmares and sleep difficulties, and several report being traumatized after having been assaulted on multiple occasions. There were also indications of fear and an increase in suicidal thoughts. In some cases the perpetrators' threats frequently continuing while the women and girls were living in the domestic violence shelters (Author 2012; Sedem and Ferrer-Wreder 2015).

Girls are described as facing multiple barriers that prevent them from seeking help (Author 2012; Blum et al. 2016). They are more isolated and alone with their problems than the average young person (Author 2007; Schlytter and Linell 2010), and in interviews they describe their fear of being rejected and isolated by their families if the violence becomes known to the community (Author 2012; Sedem and FerrerWreder 2015). A common thread in Nordic research on young people with foreign backgrounds is their strong need for, and dependency on, their families (Author 2012; DanneskioldSamsøe et al. 2011). In cases of domestic violence, these strong emotional bonds between the family members tend to make it more difficult for the victims to process their experiences of violence (Author 2012; Blum et al. 2016).

To sum up, the research evidence on children exposed to domestic violence is relatively new, and without distinctions regarding different forms of violence (Øverlien 2013). Children in general are dependent on the adult world, and the perpetrator being an attachment person has a special impact. Young female victims of HBV are in an extremely vulnerable situation when living with restrictions and control. The fact that they are minors, being in a minority ethnic group, with strong emotional bonds to their families, makes it difficult for them to leave an abusive family situation on their own. Many have also experienced trauma with severe psychosomatic symptoms. The consequences of honor-based violence are to some extent documented. However, there is a lack of a deeper understanding of how honor-based violence, and not just physical violence, affects young women's lives. Moreover, there is a lack of understanding of how different forms of violence restrict their scope for action with reference to ethnicity, culture, tradition and religion.

\section{Theoretical Framework}

Patriarchy is about male domination; however, patriarchal systems change over time and vary between societal contexts. They exist on two levels: a macro, i.e., bureaucracies, governments, laws, markets, and religions, and a micro, i.e., in interactions/interplays, families, organizations, and patterns of relationship behaviors (Hunnicutt 2009). This article focuses on micro-level patriarchal systems, and the definition used here is taken from Therborn's (2004) definition of a patriarchal family, which refers to generational and conjugal family relations or, more clearly, to generational and gender relations (Therborn 2004, p. 13). Therborn describes how a patriarchal family is organized on different levels. The parent-child relationship is characterized by formalized rules for children's obedience to, and respect and reverence for, the parents - the father rules the roost. In the patriarchal structure there is, besides the capacity to exercise power, also latent violence.

Therborn's (2004) definition of patriarchy offers a sort of patriarchal family framework. The focus is on gender and generation, with an emphasis on paternal authority. Bourdieu (1999), on the other hand, describes patriarchy as having a tangible, physical, and emotional dimension. His concepts of symbolic violence and habitus give us a broad understanding of how male dominance is produced and reproduced through norms, unspoken and tacit messages, symbols, communication, and knowledge, as well as through emotions, body language, and intonation. These concepts are central to the understanding of the whole and comprise how norms and values are transferred from the older to the younger generation. It is about embodied norms, and Bourdieu points to the essential, namely, that "the strength of the ethos [habitus] is that it is morality made flesh" (Bourdieu 1984/1995, p. 86). The term embodied describes how experiences, values, and norms are incorporated in the physical body. It is also about how they interact, influence, and shape the way we perceive the world as well as how we act in it. This happens unconsciously without our giving it any reflection, and emotions are an important dynamic. One way of understanding how this could be expressed is by using Hochschild's (1983/2003) description of feelings as both the compass of existence and a moral attitude toward actions. Symbolic violence is a soft and insidious form of violence. It is about structures and meaning systems but also about feelings, norms, and values, and, taken together, it is about how our self-image and identity are formed.

Violence is a complex phenomenon that comprises not just physical force as discrete acts intended to hurt, damage, or kill but also a range of tactics designed to intimidate, humiliate, degrade, exploit, isolate, and control (Johnson 2006; Stark 2009). Thus, Stark (2009), using the concept of coercive control, describes violent events not as separate but as elements that constantly interact in an ongoing and cumulative way. Based on victims' experiences, violence can be viewed as having fluid boundaries between overlapping events on a continuum (Kelly 1988). By using the image of a continuum, actions can be visible that otherwise would be construed as less severe. It is then possible to understand the connection and interaction between different forms of violence as well as how the different forms are repeatedly expressed in a specific context without minimizing the severity of the violent acts. For this analysis, the concept of coercive control, designed to punish, hurt, or control, and whose effects are cumulative 
(Stark 2009), is fruitful. It points to the construction and deconstruction of gender identity as the specific aim of coercive control (Stark 2009). The concept has increasingly been applied to women's experience of violence, yet not commonly used for children's and young people's (Katz 2015).

\section{Methods}

Honor-based violence as a phenomenon, and a social problem, was first noticed in Sweden in 2002, when a young woman, 26 years, was shot by her father in the family's apartment. The woman had gone out public, telling her story of control and violence from her father and brother. Moreover, she had spoken before the Swedish parliament. A speech that went viral in newspapers and TV nationwide. This homicide highlighted the situation of young women with non-Swedish background living with control and violence from their families. At this time, the concepts honor killing and honor-based violence were unknown and did not exist in the Swedish language (Author 2007).

This article focuses on young women, with non-Swedishborn parents, who, when in contact with counselors, midwives or social workers, expressed living with restrictions over their social life and sexuality with some level of control imposed by another person. Accordingly, it is young women's subjective assessment of their experiences that constituted the selection criteria and defined their inclusion in this study. The empirical material was gathered (Author 2012) between 2005 and 2008, which means the data is 10-13 years old, at a time when the Swedish government was putting significant effort into combatting HBV. During this period, HBV was treated by government, the media and the public as a primarily nonSwedish, foreign form of violence (Author 2007; Carbin 2013). Due to the focus on HBV, there have been some changes in laws according child marriage and forced marriage. However, I stress that this has no impact on the results. Today, honor-based violence still remains a social problem and the work to prevent and combat HBV is the responsibility of many actors in the Swedish society. Moreover, there is an ongoing discussion about introducing more severe penalties for offences with honor motives.

\section{The Participants}

The women included in this study came from a greater Middle East region (i.e., Middle Eastern nations and western Asia) where the concept of honor governs everyday behavior. The participants were young dependents. At the time of the interviews, seven of the eleven young women were minors. They had been exposed to a wide range of restrictions and control as well physically abused by their parents and in two cases also by a brother. In other words, it was their attachment persons who were responsible for most of the control and coercion. One family had been living in Sweden for 27 years, three families for about 20 years, and the rest for anywhere between 8 and 18 years. Of the 11 young women, 5 were born in Sweden. Six families considered themselves Muslim and two Christian, while the rest were mixed faith (Christian and Muslim). The parents were a heterogeneous group in terms of ethnicity and levels of urbanization and education (Author 2012).

\section{Procedure and Ethics}

No ethical vetting was made. This means that neither a formal consent form was distributed or a distress protocol were used. However, because of the sensitive nature of the topic and the potential vulnerability of the participants, intensive, yet informal discussions with the Regional Ethical Evaluation Board in Stockholm, and the National Swedish Board of Health and Welfare were conducted. An important dilemma to consider was whether the value of the study exceeded the risk to the participants. However, at that time there was a lack of knowledge of honor-based violence and adequate theories, moreover, the research of young people's experiences of DV was of limited extent. All together there were strong reasons for realizing the study. In addition, participants received substantial information regarding possibilities and consequences before they agreed to participate.

Contacts with the participants were established through professionals: counselors, midwives, or social welfare secretaries. About 30 young women were asked to participate; in the end, 11 gave oral consent to participate. Because of the established professional contacts, the women had, in other words, access to the kind of help that distress protocols usually put in place (Author 2012). In two cases information concerning safety of the participants became evident during the interviews. After consent from the participants the professional in point was contacted. Because several of the young women were living with threats of reprisal (and violence) from their families it was crucial to preserve their anonymity. Therefore, none of the details (such as the time and place of the interview) have been disclosed, and information that does not change the data but protects the identities of the participants (e.g., ethnicity, number, and gender of the siblings) has either been altered or removed.

As a highly qualified interviewer with extensive experience in interviewing children and adolescents on sensitive topics, I conducted a one-to-one interview with each informant. The interviews were semi-structured and addressed the past, present, and future. Open-ended questions were used to investigate family roles that the participants believed existed in their family. In some cases, the interviewees spontaneously made reference to physical violence, but no explicit questions were asked about violence. Rather, the interviewer openly 
examined what the participants thought the parents might impose if they found that their daughter had violated family norms. The interviews, which averaged about $60 \mathrm{~min}$, were audiotaped and transcribed verbatim. They took place in various locations (e.g., a youth guidance center, a social services office, a foster home).

\section{Analysis}

Thematic analysis is a method for identifying and analyzing patterns in qualitative data suited to research questions about the representation and construction of phenomena in a particular context (Braun and Clarke 2006). Although the method is usually described as a process with different stages, Braun and Clarke (2006) suggest that analysis is more of a recursive than a linear process. The present analysis takes as its starting point the accounts of violence. For the analysis, the 11 transcribed interviews were reread several times to obtain an outline of the representations of violence. The theory-oriented analysis has been recursive, and both inductive and deductive. The first series of analyses had a deductive starting point, using three types of violence, symbolic, psychological, and physical (Author 2012), as the overall themes. Expressions of power, dominance, control, and authority were recorded, and this process generated a fourth theme, labeled social violence. This form of violence refers to participants' scope for action, and here it is defined as having the scope, physically, mentally, and socially, to choose (based on age and maturity) type of education, leisure activities, friends, and boy- or girlfriends. Scope for action is a dynamic concept. It also refers to the participants being able to decide their sexuality as well as their future life partner without risking being abused by a family member or ostracized by the family and/or family community.

All four themes were rooted in the literature on violence and coercive control and deepened the understanding of how the phenomenon of domestic violence involving children could be expressed. A second series of analyses were undertaken to capture different expressions of coercive control. These new expressions were then categorized into subthemes under the four main themes. The excerpts under each main theme have been chosen because they capture not only the large variations in, but also the similarities between, the participants' experiences.

\section{Findings}

The participants' accounts showed how intertwined the different forms of violence were, how they interacted, as well the repetitive nature of the violence. The analyses revealed how the purpose of the violence varied, and to facilitate the reading, the accounts are sorted theoretically into four themes: symbolic, social, psychological, and, finally, physical violence.

\section{Symbolic Violence}

The aim of the symbolic violence was, in the participants' context, to socialize daughters to norms such as obedience and chastity. Moreover, the daughter's chastity served as a symbol of family honor. The father-daughter relationship was characterized by respect, which I interpret as a blend of entwined feelings, such as love, admiration, loyalty, shame, guilt, and fear (Author 2012). In simple terms, this mixture of feelings tells us whether we are acting appropriately - then we feel a sense of assuredness and pride-or acting inappropriately - then we feel shame, guilt, and perhaps even fear of retribution.

The subthemes of symbolic violence were twofold. First, there was heteronormativity with distinct gender roles. There was latent violence together with norms of parental, i.e., paternal, authority. All of these themes were linked to a patriarchal family. Second, there was the language of honor, together with a strong norm of the daughter's chastity as a symbol of family. The latter subthemes were, in turn, linked to honor.

Despite the heterogeneity between the families, the participants described similar norms and values, which could be summarized as traditional values in three areas: (1) a strong sexual morality, together with a tight control of women's sexuality, (2) norms of honor, which meant, among other things, a strong emphasis on family honor, which is characterized by the daughter's chastity, and (3) gendered practices, with the man primarily seen as the family provider, while the household and the children were the woman's responsibility.

In the interviews, symbolic violence was manifested by a father's silent anger and his turning his back on his daughter. Symbolic violence could also be expressed through a father's angry look or reddening face. In addition, symbolic violence could be represented by parents making the daughter feel guilt or shameful. Another way was through cultural traditions and religion that not only legitimated the norms but also strengthened and enhanced the norms.

Common for all participants was a latent violence embedded in the patriarchal family structure and the parental authority. The participants thus felt unsure whether they were at risk of being exposed to any form of violence, and this affected their scope for action. For those physically abused, the latent violence was constantly present, controlling every action.

Through their tacit messages, body language, and emotions, parents conveyed to their daughters what they were allowed and not allowed to do. Diana (aged 20) described her parents' strategies as follows: "When my parents get angry, they don't speak that much, but they show it in a way that makes you feel guilt instead." What the interviewees had in common was family patterns emphasizing parental authority. 
In addition, in most of the families, the father's authority and power were self-evident. In different ways, all 11 participants described how they avoided having an open conflict with their fathers; some claimed that they had never challenged their fathers. Mary (aged 16) described what can here be interpreted as a loyal and trusting relationship. She also explained that she had never once disobeyed or disagreed with her father. In the next quote, Amine (aged 17), on the other hand, described a quite different family situation; the family placed expectations on her and strongly demanded that she show obedience.

The most serious thing was that you should in no way disagree with your parents. I should never question anything, especially when someone else was there - then it was even worse. Obey your dad...your parents. It doesn't matter what they do. Whatever they had done, you should go back to them; whatever they do, you are supposed to forgive them. You will return to them anyway.

Actually, the picture of the father that the participants painted was contradictory or ambivalent. It contained concepts, such as controlling, severity, authority, and acts of violence. On the other hand, some of the participants described the father as a responsible man striving to build secure lives for his children. The role as a firm and dependable adult figure seemed to function as a framework that implied security, on the one hand, and restrictions on the participants' scope for action, on the other. From the daughter's perspective, i.e., as a young woman, the demand for premarital chastity was the most important of all the family norms, expressed through the metaphor of the daughter being a diamond in the rough that the family needs to polish to become a "good" woman for a future husband whom the family would choose. The norm of chastity was also explicitly expressed, as revealed by Hannah (aged 17): "I'm a girl and I have something that could be lost, you know, my virginity. That is something very, very big. The girl is, you know, she is the very symbol of the family."

All the participants described the power of the chastity norm and how it limited their scope for action. The daughter's purity symbolized family honor and pride, entailing less scope for action for the daughters compared with their brothers. The social contexts described could be summarized in an excerpt from the interview with 18-year-old Gabriela: "And so, I may think what I want, but I cannot say what I want." And common for all participants was that they were prohibited from talking about a boyfriend. However, for some, it was not fear that kept them from speaking about boyfriends as the next quote from Diana (aged 20) shows.

I've such respect for my dad. I don't know why, well, it's because he's my dad. I feel that my dad's upbringing hasn't been like that (i.e., a daughter being allowed to talk about boyfriends). I don't know. So, most of all, I think he would be disappointed if I tell him something like that. But I don't know how he would react because I've never said anything like that to him.

Respect for her father prevented Diana from talking about her boyfriend. But, it was not a fearful respect that held her back. Rather, I interpret that she felt shame at the thought of father finding out that she had violated the norm of chastity.

So, living in an environment where a father's authority is self-evident and a daughter's chastity is the norm presents obstacles for daughters. An important aspect was how respect for the father was expressed. Was it through love, admiration, loyalty, shame, guilt, or perhaps fear? The emotional bonds between the participants and their fathers were strong in most of the families. And due to their ages, the young women were dependents. Moreover, when the participants talked about their families and family relations, they generally used categories from patriarchy and honor norms to describe their situations. It was as though the participants took their situations for granted - "that's the way it is". This, in turn, indicates difficulties for them to offer resistance and initiate a change.

\section{Social Violence}

The theme of social violence describes how the norms took concrete form in the participants' daily lives by limiting their scope for action. The aim was to maintain the norms of honor. Nevertheless, the concept of social violence highlights the tension between parental authority and children's needs and vulnerability and pertains to general conditions that may exist in families with children. The lines of demarcation between parental authority and control and restrictions are not always obvious. Using the child's age and maturity as a starting point can serve as guidance for where these dividing lines are likely to be drawn.

The boyfriend ban and demands for chastity are in this theme concretized in gender segregation and discrimination. Subthemes extracted from the analysis included control over and restrictions on finance, friends, leisure time, the cell phone and the Internet, clothes, and makeup. There were also strong demands for the female participants to assume a greater role in, and responsibility for, the household chores and looking after siblings compared to their brothers. Common for all the participants was the varying restrictions on choosing a future marital partner.

One concrete example was that of the father holding the purse strings. Four participants described being restricted in doing what they want with their pocket money, i.e., they had no money to call their own. Instead, when needed it, they had to ask their fathers and in one case the mother. For Mary (aged 16), respect for parental authority was a natural aspect of the parent-daughter relationship. She claimed that she did not 
need regular pocket money. In fact, she trusted her father to give her money whenever she needed. Another example of social violence was the responsibility given to those participants with younger siblings. The responsibility was like that of a parent for a child. At the time of the interview, Sonya (aged 16) was living in foster care, protected from severe paternal abuse. During the interview, she cast her mind back to when she was 13 years old and still living at home with both parents and younger siblings as the next quote recalls.

It was school and then home to take care of the household, clean, cook, and look after my siblings. I wasn't allowed to meet friends, and if I wanted to go out, I was only allowed to stay near the house, in the garden, where my parents could see me. So if I met my friends, it was near my home.

There were also examples of social violence related to the norms of chastity. For instance, several of the participants described restrictions on their leisure time and meeting friends, especially boys after school. Three of them could only meet a small number of female friends whom their fathers had chosen. When Raquel (aged 17) was almost 15 years old, her father had discovered that she had a boyfriend despite the strict ban that her parents had introduced. For Raquel, that marked the beginning of tighter restrictions.

He started to limit my circle of friends. 'I don't like her, and that girl you're not allowed to see.' Well, but who can I be with? I've no friends left. You have rejected everyone. And that's the way it was.

Such parental authority was an established way of life for the participants, regardless of their age, as long as they lived at home with their parents. Ebony (aged 19), gave a detailed description of her mother's strict control: no boyfriends, prohibited from talking with friends on a cell phone, and female friends could sometimes visit her at home, but male friends were not allowed to. In her mother's eyes, Ebony was still a child who had to obey.

The theme of social violence is that of the parents trying to maintain the family norms in their daily lives in a new country, and in a new societal context with different values and norms, especially regarding family issues, gender equality, and youth sexuality. For the participants, it meant restrictions on several areas of their lives. However, the strong demands for obedience made it difficult for the young women to choose a life of their own.

\section{Psychological Violence}

The third theme, psychological violence, constitutes both symbolic and social violence. It does not affect the physical body, furthermore, its principal aims were in the participants' context to ensure that family norms are adhered to and the family's honor is preserved.

Several subthemes related to psychological violence emerged from the interviews, including verbal abuse, silence, degrading behavior, humiliating acts, violation of integrity, isolation, confinement, repudiation, rejection, and threats of violence and death threats. A special form of psychological violence was emotional blackmail, which pertains to feelings of unpleasantness and describes actions and attitudes (also silence) that, by generating feelings of shame and guilt, extort obedience and restrict the victim's scope for action. The stories of emotional blackmail came mostly from those families where the fathers employed physical violence. The interviews revealed that it was the mothers who used this form of violence to force the daughters to obey their fathers.

A form of psychological violence as a means of exercising power was silence. Saba, 17 years old at the time of the interview, described how afraid she was when she first discovered that she was pregnant at the age of 15 . She was well into her pregnancy before letting her sister know. The sister then told their aunt, who passed this information on to the mother. Finally, when the mother told the father, Saba was five months pregnant, and it was too late for an abortion. The father was extremely angry, but Saba rejected his request that she give the baby up for adoption. In the end, Saba received support from her mother, and so the baby remained with Saba and her family. After discovering the pregnancy, the father no longer spoke to Saba, who, at the time of the interview, was living with her baby in a separate part of the family's big house. Almost two years had passed, and although Saba's father occasionally babysat his grandchild, he never spoke to his daughter.

Below is an example of psychological violence, with an emphasis on degrading behavior and humiliating acts in the light of the norm of chastity. In some cases, the events only occurred once, such as the one Lula (aged 17) described when she was just 13 years old.

My father ordered my mother to take me to the youth guidance center for a medical examination and to see whether I was still a virgin. However, the midwife and the counselor at the center said that it wasn't possible to check my virginity.

Fortunately, she never underwent an examination; nevertheless, Lula said that the incident had a profound and lasting impact on her.

The participants described instances of psychological violence, such as when fathers, and, in some cases, brothers, repeatedly checked the participants' bags and cell phones. As noted earlier in this article, the norm of chastity means that the daughter's virginity is the symbol of family honor. Hence, 
the word 'whore' is the strongest term a father can use to illustrate how much he detests his daughter as a person. When interviewed, Sonya (aged 16) recalled her father's words when she was living with her family.

For instance, he would say, 'Whore. All your friends are whores' and 'you will be exactly like them.' You know, it was nothing I could do. Just bite the bullet, look down, and walk away. But when it happens every day, and it's your own dad, then you can't stand it. It'll be too much. It'll never stop. Do I have to live like that? I was 14 years old. Was I really supposed to live like that for another four years until I come of age? I just couldn't stand it.

Another form of psychological violence pertains to direct and indirect threats, in this instance stories told by the participants about the repercussions of physical violence. These threats could be expressed either verbally or through body language. In her interview, Lula (aged 17) described silent, yet visible, threats from her father. She knew without his saying a word that he was angry: "You feel it; his face becomes red with anger; he begins to come closer, opens his eyes widely, and..." This was a signal for Lula to go to her room to avoid physical violence, which she had experienced ever since she was a young child.

Another participant (Amine age 17) recalled how her father had threatened to kill her if he discovered that she had been with a boy or if someone saw her talking to a boy. Amine had been physically abused by her father but also by her mother. She had also seen her parents physically abuse her siblings, and these memories made the threats more real and frightening. Amine went on to explain that she had never gone against her father's will. The other participants were unsure as to whether or not their fathers would have actually carried out their threats.

Psychological violence is a form of violence in which the choice of expression and act affects the victim, not physically but emotionally. In the participants' context, the norms of honor and demands for chastity were not just matters for the young women. The fact that daughters' chastity is the symbol of family honor involved all the family members but also the surrounding social context, i.e., the ethnic collective. And, in the end, it was how fathers valued and handled the reactions of relatives and the ethnic collective that restricted young women's scope for action.

\section{Physical Violence}

The fourth theme is physical violence, the aim of which is, above all, to punish disobedience or a violation of family norms. Unlike the previous themes, fewer participants (5 out of 11) had first hand accounts of this one. According to Mary (aged 16), her parents were aware of the fact that physical violence was not a parenting option. Mary mentioned the following: "So it doesn't help if you get beaten-you have to speak, you know, talk."

Participants' references to physical violence covered various acts. Fathers were mainly responsible for the violence, in a couple of families it was also brothers, and in one family it was the mother as well. Several subthemes regarding physical violence emerged from the data: maltreatment, grievous bodily harm, banishment, abduction along with a forced engagement and attempted murder. In the interviews, material violence was represented by the father's destructive actions, e.g., destroying the daughter's computer and cell phone.

During her childhood, Sonya (aged 16) lived under constant threat and had also been exposed to different forms of paternal violence. She remembered a particular occasion when her father had discovered that she had been chatting with a boy on the Internet. "He hit me really hard that time, and he broke my cell phone by throwing it at the wall. He also removed the computer from my room."

For Lula (aged 17), the situation was extremely tense. She reported a childhood were she and her siblings had been exposed to the father's violence using his fists, a belt, and pulling her hair. The social services knew about the family situation. Indeed, Lula had been placed in foster care, and in safe houses twice, because of DV. However, she always chose to return home because she longed to be with her family. Lula was not allowed to go out without her father's permission, and if she did, she had to be chaperoned by a parent. At the time of the interview, this situation had been going on for almost six months, and her father's permission was required before the interview could take place at a social services office. During the interview, Lula compared her own situation with that of a caged bird: "[Dad] says to me: 'go to your room.' Then he closes the door and takes my cell phone and keys and locks the door-not to my room, but the front door."

Lula also reported having been physically abused by an older brother. In the excerpt below, she recalls an incident when her brother had found out that she had been seen with male friends.

My dad doesn't beat me like that. You know, when my brother hit me; it's not like he beats a girl, but it's like he beats [a guy]. My dad has beaten me like that twice. My brother, however, has beaten me on several occasions. My brother came home and then began to hit me. I was then lying on the floor on my back, and he placed his foot on my stomach. My brother is really tall, and I'm, you know, after all, small compared with him.

Raquel's story differed somewhat from Lula's. Both describe restrictions and severe physical violence. But, unlike Raquel (aged 17), Lula reported a constant presence of different forms of childhood violence. Raquel, on the other hand, said that she 
had not been physically abused as a child. The very first time Raquel's father hit her was when he discovered that his then 15 -year-old daughter had a boyfriend. This was also the first time Raquel had ever argued back.

At first, I was cheeky and continued to answer back, but then he kept on beating me. I got a cracked lip and I have a scar somewhere on my eyebrow. At the time, I was trying to run out of my room, but he held the door so I couldn't leave.

For Raquel, this incident marked the start of an escalation of violence, in terms of frequency, severity, and different forms. This had a number of consequences: she fled the family home on several occasions, was forced into an engagement in the family's country of origin and had a teenage pregnancy. When Raquel's father found out about her pregnancy, she had already left home to live with her boyfriend. In the interview she recounted her father's death threat when she became pregnant and refused to have an abortion. On one occasion, they bumped into each other on a train station platform. The sight of his pregnant daughter enraged him, and without warning, he pushed Raquel onto the tracks. Raquel described her vulnerability and needing support from the adult world. Fortunately, her brother came running out and pulled her up to safety just seconds before the train whizzed by. At the time of the interview, Raquel was safe and living in foster care with her baby.

The theme of physical violence meted out by fathers, and by a couple of brothers, refers to punishment for having violated family norms and besmirched the family's honor and reputation. The violence by one of the mothers refers to the children's upbringing and a conflict-ridden family as well as family members separated due to migration. In one family there was mention of drug abuse as a contributory cause. Some families had had family conflicts and experienced war, but there were also issues regarding migration, including separation, uncertainty, criminality and conflicts, which emerged from the interviews as possible contributory causes of the violence.

\section{Discussion}

Common for a child's position in an honor- or non-honorrelated context is their vulnerability and dependency on the parents or guardians for a happy childhood. Cater and Sjögren (2016) point to the fact that the perpetrator is also a parent/an attachment person which is an aggravating circumstance. In contrast to previous studies (Cater and Sjögren 2016; Weinehall 1997/2005), the physical violence described by the participants was not alcohol-related. The physical violence described, was often predictable and the reasons for fathers resorting to physical violence were to calm the father's own feelings as well as protect the family's dignity and respectability. Another important finding is how domestic violence concerning a child is embedded in her entire childhood. However, like other studies (Katz 2015; Weinehall 1997/ 2005), it was not just the physical violence that had an effect; even nonphysical violent parental acts restricted participants' scope for action. The overall findings suggest a limited potential for resistance, but, and this is important, it does not mean that there was no resistance. Put together, participants were living with an all-pervasive violence, and in a way, they were taking their situations for granted, which is in line with Øverlien's (2013) study of a group of children who lived with patriarchal terrorism.

The accounts of honor-based violence could be interpreted as coercive control (Stark 2009). Stark's concept concerns adults and points to the construction and deconstruction of gender identity as the specific aim of coercive control, i.e. gender as dimension of power. The core of this article, on the other hand, comprises (family) relations, with gender, but also generation as dimension of power. The analysis points to children's best, vulnerability and dependency. In the young women's families, males dominate over females, and to maintain honor and respect, males need to control the family, above all, the daughters and their sexuality. In the families there are a pattern, constantly ongoing, of parental/paternal dominance. When the physical violence is in use, it is often interwoven with other forms of violence, such as threat, surveillance and isolation. However, to have control, physical violence is not necessarily needed. In some cases, violence is also expressed in non-verbal ways; e.g. a rigorous eye.

Using Bourdieu's concepts of symbolic violence and habitus has given an understanding of how domination is created and maintained by, among other things, emotions that arise in the interaction between individuals of different social rank and age. Furthermore, using symbolic violence as a theoretical lens has highlighted important aspects of the significance of the context. The family organization, with a clear hierarchy and distinct gender and generation roles (Therborn 2004), underpin the parental, i.e. paternal authority. In addition, the analysis points to the importance of norms and discourses (Nason-Clark et al. 2017; Westenberg 2017); i.e. honor and the daughter's role as a symbol of family honor, and their significant impact on the participants' scope for action. By describing and valuating themselves from criteria that contributed their disadvantages, in a way, the young women contributed to their own subordination, which is a form of symbolic violence (Bourdieu 1999). It is also a part of the construction of their gender identity, which in turn can be interpreted as a part of their habitus (ibid). In families were honor plays a key role in daily lives, males have access to social capital which give them the preferential right of interpretation (Bourdieu 
1999; Gill 2014). Young women, on the other hand, are limited by their habitus, they adapt their behavior and scope for action according to the context of their family and childhood (Bourdieu 1999).

By way of conclusion, a theoretical model of different forms of violence is outlined using the concepts of coercive control, symbolic violence, and habitus as a basis. The violence was expressed in numerous acts and overlaps, interacts, and strengthen one another without being ranked in a clear order. The change in violence grows in what could be described as a continuum, from one form of violence to another. Moreover, it was repeated daily. However, in some cases, the change stopped before it became physical violence. Gender and the position in the family hierarchy are decisive for which type of violent act and what form of violence are employed. The emphasis on male authority means that the father had an array of violence at his disposal. For the mother, the situation was different. In families where the father/husband used physical violence, the interviewees gave accounts of emotional blackmail that the mother used against them to conciliate between the daughter and the father.

The concept of respect mirrors the content of the social bonds between father and daughter and constitutes the nature and dynamics of coercive control. It also illustrates how the norms are embodied using emotions as a driving force. The milder forms of merging actions change but not necessarily into more severe forms of violence. Even if there is a temporal aspect, symbolic violence is the most fundamental kind. This is probably the case because of its invisible and pervasive nature.

\section{Conclusion}

This article has suggested how nonviolent controlling behaviors affect young women's scope for action and pointed to daughters' vulnerable situation in a patriarchal family. A topic that to date has received almost no attention in research, but primarily as honor-based violence. The results of this study are a starting point for further research in this area, highlighting the link between social/cultural norms and discourses, sometimes legitimated by religious argument, and forms of coercive control. Employing a coercive control-based definition in future children/young people and domestic violence work, and moving beyond the concept of honor-based violence, would enable us to develop a deeper understanding of these young people's lived experiences and support needs. Using the concepts of symbolic violence and habitus will also enable us to develop a deeper understanding of the significance of the context as well the importance of scrutiny the emotional dimension in the families.
Open Access This article is distributed under the terms of the Creative Commons Attribution 4.0 International License (http:// creativecommons.org/licenses/by/4.0/), which permits unrestricted use, distribution, and reproduction in any medium, provided you give appropriate credit to the original author(s) and the source, provide a link to the Creative Commons license, and indicate if changes were made.

Publisher's Note Springer Nature remains neutral with regard to jurisdictional claims in published maps and institutional affiliations.

\section{References}

Author, (2007). Personalens möten med utsatta flickor. [the work of professionals in combating honor-based violence]. Sköndals arbetsrapportserie nr 48. Stockholm: Ersta Sköndal högskola.

Author, (2012). Om patriarkat, motstånd och uppbrott: Tjejers rörelser $i$ sociala rum [patriarchy, resistance and breaking up: Young girls movement in social spaces]. [thesis]. Malmö: Égalité.

Bates, L. (2017). Honour-based abuse in England and Wales: Who does what to whom? (unpublished thesis). Faculty of Social Sciences and law, School for Policy Studies, University of Bristol. https://ethos.bl. uk/OrderDetails.do?uin=uk.bl.ethos. 723493

Berkel, L., Vandiver, B. J., \& Bahner, A. (2004). Gender role attitudes, religion, and spirituality as predictors of domestic violence attitudes in white college students. Journal of College Student Development, 45(2), 112-133.

Blum, E., Braiden, R., \& Heinonen, T. (2016). Service delivery considerations in dealing with honour-based violence. Canadian Ethnic Studies, 48(3), 129-148. https://doi.org/10.1353/ces.2016.0029.

Bourdieu, P. (1984/1995). Sociology in question. London: Sage.

Bourdieu, P. (1999). Den manliga dominansen [Masculine domination]. Gothenburg: Daidalos.

Braun,V., \& Clarke, V. (2006). Using thematic analysis in psychology. Qualitative Research in Psychology, 3(2), 77-101. https://doi.org/ 10.1191/1478088706qp063oa.

Carbin, M. (2013, Sep.-Oct). The requirement to speak: Victim stories in Swedish policies against honour-related violence. Women's Studies International Forum, 46, 107-114. https://doi.org/10.1016/j.wsif. 2013.12.002.

Cater, Å. K., \& Sjögren, J. (2016). Children exposed to intimate partner violence describe their experiences: A typology-based qualitative analysis. Child and Adolescent Social Work Journal, 33(6), 473486. https://doi.org/10.1007/s10560-016-0443-7.

Danneskiold-Samsøe, S., Mørck, Y., \& Sørensen, B. W. (2011). Familien betyder alt: Vold mod kvinder i etniske minoritetsfamilier [The family means everything: Violence Against Women in ethnic minority families]. Frederiksberg: Frydenlund Academic.

Durrant, J. E., \& Ensom, R. (2017). Twenty-five years of physical punishment research: What have we learned? Journal of the Korean Academy of Child and Adolescent Psychiatry, 28(1), 20-24. https://doi.org/10.5765/jkacap.2017.28.1.20

Ertürk, Y. (2009). Towards a post-patriarchal gender order: Confronting the universality and the particularity of violence against women. Sociologisk Forskning, 46(4), 61-70.

Gill, A. K. (2014). Introduction: 'Honour' and 'honour'-based violence: Challenging common assumptions. In A. K. Gill, C. Strange, \& K. Roberts (Eds.), Honour' killing and violence: Theory, policy \& practice (pp. 1-26). London: Palgrave Macmillan. https://doi.org/ $10.1057 / 97811372895681$.

Grogan-Kaylor, A., Ma, J., \& Graham-Bermann, S. A. (2018). The case against physical punishment. Current Opinion in Psychology, 19, 22-27. https://doi.org/10.1016/j.copsyc.2017.03.022 
Hayes, B. E., Freilich, J. D., \& Chermak, S. M. (2016). An exploratory study of honor crimes in the United States. Journal of Family Violence, 31(3), 1-12. https://doi.org/10.1007/s10896-016-9801-7.

Hochschild, A. R. (1983/2003). The managed heart: Commercialization of human feeling. Los Angeles: University of California Press.

Hunnicutt, G. (2009). Varieties of patriarchy and violence against women: Resurrecting "patriarchy" as a theoretical tool. Violence Against Women, 15(5), 553-573. https://doi.org/10.1177/ 1077801208331246.

Jernbro, C., \& Janson, S. (2017). Våld mot barn 2016: En nationell kartläggning [violence against children 2016: A national survey]. Stockholm: Allmänna Barnhuset.

Jernbro, C. A., Eriksson, U. B., \& Janson, S. (2010). Young adults' personal views on child abuse. Nordic Journal of Social Research, 1, 8-23. https://doi.org/10.7577/njsr.2045.

Johnson, M. P. (2006, Nov). Conflict and control: Gender symmetry and asymmetry in domestic violence. Violence Against Women, 12(11), 1003-1018. https://doi.org/10.1177/1077801206293328.

Katz, E. (2015). Beyond the physical incident model: How children living with domestic violence are harmed by and resist regimes of coercive control. Child Abuse Review, 25(1), 46-59. https://oi.org/10.1002/car. 2422.

Kelly, L. (1988). Surviving sexual violence. Cambridge: Polity Press.

Nason-Clark, N. (2004). When terror strikes at home: The interface between religion and domestic violence. Journal for the Scientific Study of Religion, 43(3), 303-310. https://doi.org/10.1111/j.14685906.2004.00236.x.

Nason-Clark, N., Fischer-Townsend, B., Holtmann, C., \& McMullin, S. (2017). Religion and intimate partner violence: Understanding the challenges and proposing solutions. Oxford: Oxford University Press.

ONS (2018). Abuse during childhood: Findings from the crime survey for England and Wales, year ending March 2016. Retrieved from https:// www.ons.gov.uk/peoplepopulationandcommunity/crimeandjustice/ a r t i c l e s / a b u s e d u r i n g c h i l d h o o d / findingsfromtheyearendingmarch2016crimesurveyforenglandandwales

Øverlien, C. (2013). The children of patriarchal terrorism. Journal of Family Violence, 28(3), 277-287. https://doi.org/10.1007/s10896013-9498-9.

Schlytter, A., \& Linell, H. (2010). Girls with honour-related problems in a comparative perspective. International Journal of Social Welfare, 19(2), 152-161. https://doi.org/10.1111/j.1468-2397.2009.00651.x.

Sedem, M., \& Ferrer-Wreder, L. (2015). Fear of the loss of honor: Implications of honor-based violence for the development of youth and their families. Child \& Youth Care Forum, 44(2), 225-237. https://doi.org/10.1007/s10566-014-9279-5.

Smagur, K. E., Bogat, G. A., \& Levendosky, A. A. (2017). Gender role and gender as predictors of behavior problems in children exposed to intimate partner violence. Journal of Family Violence, 32(2), $157-$ 168. https://doi.org/10.1007/s10896-016-9890-3.

Stark, E. (2009). Coercive control: How men entrap women in personal life. Oxford: Oxford University Press.

Therborn, G. (2004). Between sex and power: Family in the world, 19002000. New York: Routledge.

UNFPA (2000). Könsdiskriminering måste upphöra. The State of World Population 2000. https://www.un.dk./swedish/unfpa-2000.htm.

Weinehall, K. (1997/2005). "Take my father away from home": Children growing up in the proximity of violence. In M. Eriksson, M. Hester, S. Keskinen, \& K. Pringle (Eds.), Tackling men's violence in families: Nordic issues and dilemmas (pp. 137-154). Bristol: Policy Press.

Westenberg, L. (2017). When she calls for help': Domestic violence in Christian families. Social Sciences, 6(71). https://doi.org/10.3390/ socsci60300. 